Isles. These conclusions follow from determinations of lead isotope abundances of 98 galena specimens from Great Britain and Ireland, the ages being calculated using the Holmes-Houtermans model (Philosophical Transactions of the Royal Society of London. Series A: Mathematical and Physical Sciences. Lead Isotope Abundance Studies on Mineral Occurrences in the British Isles and their Geological Significance. By S. Moorbath. Pp. 295-360. London: Royal Society. 21s.). These model ages show good agreement with published values of the absolute ages of genetically associated igneous rocks. Since most British galenas are vein-type deposits of epigenetic type which have traversed sedimentary and igneous rocks, this agreement suggests that the assumptions of the HolmesHoutermans model do not contradict the hypothesis of a crustal rather than a mantle origin for lead ores. This view is in harmony with one of an early differentiation of the Earth's crust and repeated rejuvenation of ancient fold belts, rather than with one of continual continental accretion around marginal mobile belts.

\section{Forest Research in Sweden}

THE recent volume of reports from the Forest Research Institute of Sweden is devoted to a variety of subjects, and Scots pine is prominent among them (Meddelanden från Statens Skogsforskningsinstitut, Band 49, 1960-1961. Reports of the Frorest Research Institute of Sweden, Vol. 49. Pp. iv +580. Stockholm: Statens Skogsforskningsinstitut, 1961). It has been found that mortality among pine seedlings caused by parasitic fungi can be prevented by presowing treatment of the soil with methyl bromide. Storage of pine pollen is best done at very low temperatures $\left(-18^{\circ} \mathrm{C}\right.$.) if the fertilization capability is to be preserved. Although there is nothing surprising in the conclusion reached that heavy low thinnings for Scots pine are economically and biologically superior to heavy crown thinnings, this is supported by a description and analysis of thinning experiments over a period of 54 years. A very good article on the sawfly, Diprion (Microdiprion) pallipes Fall., is well illustrated and includes an excellent colour plate. Another article on forest entomology is concerned with the larch shoot moth, Argyresthia laevigatella H.S. The reports are attractively presented and well supported with references. Four reports are in English, and of the remaining six there are English summaries for four and German sum. maries for two--those on forest entomology.

\section{Indian Forest and Forest Products Terminology}

PART 1 of a publication recently issued as an Indian Forest Record, entitled Indian Forest and Forest Products Terminology, deals with the general subject of forests (Vol. 10, No. 6. Pp. iv +125-215. Delhi: Manager of Publications, 1961. Rs. 6.00 nP., 9s. 6d.). This is a glossary of some 2,000 terms used in sylviculture, protection, mensuration, management, ecology, soil science and allied subjects. Most of them have been taken from the British Commonwealth Forest Terminology, while others have been gleaned from other well-known appropriate glossaries, and there are a few terms which are particular to India. The terms included in this glossary are comprehensive and correct, but 'assortment table' is perhaps too narrowly defined. It can be argued that 'crop' is used in an unfortunate sense at times, but this is a common failing nowadays when the growing of trees is too much likened to an agricultural crop.
On the other hand, the correct 'to bark' is insisted on and improper 'to debark' is, according to the glossary, to be deprecated. Three appendixes provide classifications of the principal sylvicultural systems, trees by crown classes and thinning densities. This glossary is obviously intended for use in India and there it will be welcomed; it is a pity that a more convenient format and hard covers had not been provided. Part 2, dealing with forest products, will be published at a later date.

\section{Gerontology and Geriatrics in the U.S.S.R.}

Some of the present-day developments in gerontology and geriatrics in Russia were discussed at a conference in Moscow during 1960. A brochure issued by the Division of General Medical Sciences, Center for Aging Research of the U.S. Department of Health, Education and Welfare, provides a trans. lation of all the papers in summary form (Public Health Service Publication No. 884. Pp. viii +81 . Washington, D.C.: Government Printing Office, 1961. 35 cents). These range from activities of the Republic Gerontological Society of the Kazakh S.S.R.; structural aspects of ageing; psychiatry of old age as an independent branch of psychiatry; organization and methods of conducting group physical culture activities among middle-aged and elderly persons; the effect of physical exercise on the cardiovascular system of elderly persons; the causes of death among elderly persons in one region of an industrial city of Zazakhstan; senile dementia; features of cataract surgery on persons $80-118$ years of age; treatment of certain diseases of elderly persons with a 2 per cent solution of novocaine; the work capacity of persons with cerebral atherosclerosis; and premature senility and the treatment of cerebral artherosclerosis.

\section{The Origin of Life}

THE latest version of A. I. Oparin's hypothesis of the origin of life on the Earth is given by its author in a short article (Priroda, 7, 5; 1961). The story begins with an abiogenic generation of amino-acids in the primitive atmosphere, their gradual synthesis into proteins and the eventual formation of the 'primitive broth', composed of polymolecular 'concervate' drops, which eventually give rise to bacteria and blue-green algae. Future aeronauts may discover life existing on other planets, and carbon meteorites suggest the possibility of such an occurrence. Wider concepts of the probability of life in the cosmos, the progress of evolution and the future of mankind are discussed elsewhere by A. I. Baumstein (Priroda, 12, $76 ; 1961)$.

\section{International Geological Congress :}

Twenty-second Session

THE twenty-second session of the International Geological Congress will be held in New Delhi during December 14-22, 1964. The following subjects have been provisionally selected for discussion, each subject corresponding to a section of the Congress: (1) geology of petroleum; (2) geological results of applied geophysics; (3) Cretaceous-Tertiary boundary including volcanic activity; (4) rock deformation and tectonics; (5) genetic problems of ores; (6) minerals and genesis of pegmatites; (7) plateau basalts; (8) Tertiary mammals; (9) Gondwanas; (10) Archæan and Pre-Cambrian geology; (11) Himalayan and alpine orogeny; (12) isostasy; (13) charnockites; (14) laterite; (15) sedimentary 